\title{
Immune humoral response of young lambs naturally infested by Oestrus ovis (Diptera: Oestridae)
}

Resposta imune humoral de cordeiros jovens naturalmente infestados por Oestrus ovis (Diptera: Oestridae)

Bruna Fernanda da Silva ${ }^{1 *}$; César Cristiano Bassetto²; Alessandro Francisco Talamini do Amarante ${ }^{2}$

${ }^{1}$ Programa de Pós-graduação em Ambiente e Saúde, Universidade do Planalto Catarinense - UNIPLAC, Lages, SC, Brasil

${ }^{2}$ Departamento de Parasitologia, Instituto de Biociências, Universidade Estadual Paulista - UNESP, Botucatu, SP, Brasil

Received January 22, 2018

Accepted May 17, 2018

\begin{abstract}
Twenty-six newborn lambs were evaluated for 21 weeks, from birth to slaughter, to assess their plasma anti-Oestrus ovis immunoglobulin (IgG) using the ELISA technique. On the last day of sampling, all the lambs were slaughtered and O. ovis larvae were recovered, quantified and identified according to the larval stage. High levels of IgG were observed over the first three weeks of life, thus indicating that antibodies are transferred via colostrum from ewes to lambs. Afterwards, the antibody levels declined progressively until the lambs were 11 weeks of age and subsequently started to increase again when they were around 13 weeks of age, reaching the apex on the last week of sampling. All the lambs were parasitized with different larval stages of $O$. ovis, with an average of 39 larvae per lamb, and the intensity of the infestation ranged from 10 to 97 larvae. However, there was non-significant correlation coefficients between IgG levels and $O$. ovis larval burden $(\mathrm{P}>0.05)$. In conclusion, although the lambs became infested with $O$. ovis at an early age, the larval burden was not associated with specific IgG levels.
\end{abstract}

Keywords: Myiasis, sheep, immunoglobulin G, immune response, dyspnea.

\section{Resumo}

Vinte e seis cordeiros recém-nascidos foram avaliados por 21 semanas, desde o nascimento até o abate, para avaliar os níveis plasmáticos de imunoglobulina (IgG) anti-Oestrus ovis utilizando-se a técnica de ELISA. No último dia de coleta, todos os cordeiros foram abatidos e as larvas de $O$. ovis foram recuperadas, quantificadas e identificadas de acordo com o estádio larval. Foram observados altos níveis de IgG nas primeiras três semanas de vida, indicando que os anticorpos são transferidos por meio do colostro das ovelhas para os cordeiros. Posteriormente, os níveis de anticorpos diminuíram progressivamente, até os cordeiros completarem 11 semanas de vida. Os níveis de IgG começaram a aumentar novamente a partir de 13 semanas de idade, atingindo o ápice na última semana de coleta. Todos os cordeiros estavam parasitados com diferentes estádios larvais de O. ovis com uma média de 39 larvas por cordeiro, e a intensidade da infestação variou de 10 a 97 larvas. Porém, náo houve correlaçáo significativa entre os níveis de IgG e a carga larval de O. ovis ( $\mathrm{P}>0,05)$. Em conclusão, embora os cordeiros tenham sido infestados com $O$. ovis ainda jovens, a carga larval náo foi associada a níveis específicos de IgG.

Palavras-chave: Miíase, ovinos, imunoglobulina G, resposta imune, dispneia.

\section{Introduction}

Oestrus ovis L. (Diptera: Oestridae) is the agent for a very common cavitary myiasis affecting sheep and goat hosts worldwide (CEPEDA PALACIOS et al., 2011). The larvae of this fly are obligate parasites of the nasal and sinus cavities and may severely impair the health of infested animals because of the respiratory discomfort that they

*Corresponding author: Bruna Fernanda da Silva. Programa de Pós-graduação em Ambiente e Saúde, Universidade do Planalto Catarinense - UNIPLAC, Avenida Castelo Branco, 170, Bairro Universitário, CEP 88509-900, Lages, SC, Brasil. e-mail: brusilvabio@gmail.com cause, such as seromucous or purulent nasal discharge, frequent sneezing and dyspnea (ZUMPT, 1965; DORCHIES et al., 1998).

Besides their hosts of predilection, $O$. ovis has been reported in wild animals as Ovis canadensis (CAPELLE, 1966), Lama glama (GOMEZ-PUERTA et al., 2013), Ovis orientalis musimon (MORENO et al., 1999, 2015), Capra sibirica (SÁNCHEZ et al., 2017) and Ammotragus lervia (BARROSO et al., 2017). This larvae is also common cause of ophthalmomyiasis in humans (FASIH et al., 2014; SANTE FERNÁNDEZ et al., 2017; RAO et al., 2018). 
The epidemiology of this parasite has been investigated in detail around the world and the prevalence and intensity of its infestations are influenced mainly by climatic conditions (CARACAPPA et al., 2000; DORCHIES et al., 2000; ARSLAN et al., 2009; GRACIA et al., 2010; GEBREMEDHIN, 2011; HANAN, 2013; MATOS et al., 2013; HIDALGO et al., 2015; SALEEM et al., 2017). In Brazil, until recently, oestrosis was considered to be a neglected disease despite its increasing occurrence (SILVA et al., 2012a). The only studies that had been conducted were in the south region, where one of the biggest sheep populations of Brazil is concentrated (RIBEIRO et al., 1990; RAMOS et al., 2006). However, sheep farming has spread throughout the country and clinical signs of oestrosis are becoming common in sheep flocks. This has stimulated production of studies in other regions of Brazil, such as in the southeast (SILVA et al., 2012a, b, c, 2013), center-west (SCHENKEL et al., 2012; ATAÍDE \& CANSI, 2013; MUSTAFA et al., 2015), south (CARVALHO et al., 2015) and northeast (VASCONCELOS et al., 2016).

Oestrosis is generally diagnosed based on clinical signs and postmortem detection of larvae. However, from a scientific as well as an animal welfare point of view, use of invasive methods like necropsy for diagnosing oestrosis and determining the intensity of parasitism limits the research possibilities (ARIAS et al., 2014). The major symptoms of infestation (nasal discharge and frequent sneezing) are immune-mediated, i.e. they depend on acquisition of an immune response against the parasite, and the intensity of this response. Not all infested sheep show clinical signs of oestrosis (ANGULO-VALADEZ et al., 2011; SILVA et al., 2012a), which makes it difficult to infer the degree of incidence of the disease.

The results from previous studies demonstrated that the ELISA test (enzyme-linked immunosorbent assay) is a valid technique for detecting $O$. ovis antibodies in sheep (ALCAIDE et al., 2005; ANGULO-VALADEZ et al., 2008; SILVA et al., 2012b; ARIAS et al., 2014) and might be useful as an alternative to postmortem examination. Therefore, the present study was carried out to evaluate the immune humoral response among lambs, from birth to slaughter, in terms of anti-O. ovis IgG levels.

\section{Materials and Methods}

\section{Study location}

This trial was conducted at the sheep farm of the Sáo Paulo State University (Universidade Estadual Paulista, UNESP), which is located in Botucatu, state of São Paulo, Brazil (22 82' S; $48^{\circ}$ 4' W; $613 \mathrm{~m}$ above sea level). The study was carried out from July 3, 2011 (the beginning of lambing), to January 3, 2012. Previous studies conducted in the same area had shown high incidences of oestrosis among sheep between the months of September and December (SILVA et al., 2012a, c).

Meteorological data (average temperatures and rainfall) were obtained from the Department of Environmental Science, Agronomical Science College, UNESP, which is located $8 \mathrm{~km}$ from the experimental site (Figure 1).

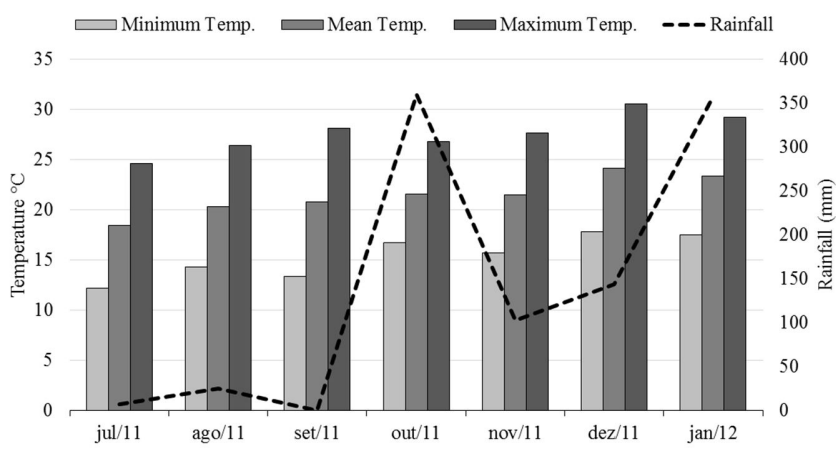

Figure 1. Average maximum, average minimum and mean monthly temperatures and monthly rainfall from July 2011 to January 2012. Source: Department of Environmental Sciences, Agronomical Science College, São Paulo State University (UNESP), Botucatu, state of São Paulo.

\section{Animals}

The immune humoral response in terms of anti-O. ovis immunoglobulin $\mathrm{G}$ ( $\mathrm{IgG}$ ) levels was evaluated fortnightly for 21 weeks, from July 2011 to early January 2012, among 26 crossbred Bergamacia lambs, from first week of birth to slaughter, using the ELISA technique. The plasma samples were collected from the first week of birth until the day of slaughter with approximately 21 weeks of age, when the $O$. ovis larvae were recovered, quantified and identified according to the larval stage.

It is worth mentioning that these lambs were raised in an environment propitious for occurrences of oestrosis and did not receive any antiparasitic drug treatment during the study.

All the lambs were vaccinated with a Clostridium vaccine (Sintoxan ${ }^{\oplus}$ Polivalente, Merial, Brazil) at 4 and 6 weeks of age. At all times, the lambs were kept on pasture of Panicum maximum (Tanzania grass) and received daily supplements of $800 \mathrm{~g}$ of commercial concentrate after weaning. Weaning occurred when they were approximately 10 weeks old. Water and mineral salts were available ad libitum.

All procedures were performed in accordance with the animal welfare standards and the study was approved by the university's animal research ethics committee (UNESP protocol 261-CEEA).

\section{Enzyme-linked immunosorbent assay (ELISA)}

IgG levels in plasma samples were determined against crude extract (CE) antigen from the second instar (L2) of O. ovis larvae, based on prior reports of successful use of this antigen (SILVA et al., $2012 \mathrm{~b}$ ). The antigen production and ELISA procedures were previously described by Silva et al. (2012b).

Briefly, polystyrene microtiter plates (Nunc, Rochester, NY, USA) were coated with $O$. ovis antigen and the plates were incubated overnight at $4{ }^{\circ} \mathrm{C}$. All subsequent incubations were carried out for $1 \mathrm{~h}$ at $37^{\circ} \mathrm{C}$. Between each step, the plates were washed three times. After coating, blocking was carried out and the plasma samples were diluted and applied in duplicate. The plates were then incubated with peroxidase-conjugated rabbit anti-sheep 
IgG diluted at 1:10,000 (A130-101P, Bethyl Laboratories, Inc., USA). Finally, OPD substrate solution (1,2-phenylenediamine dihydrochloride; Dako, Denmark) was added to each well and the enzyme reaction was allowed to proceed. The plates were read at $492 \mathrm{~nm}$ by using an automated ELISA reader (Biotrak II; Amersham Biosciences, Little Chalfont, UK). The results regarding IgG were expressed as the percentage of the optical density (OD) value of the positive-reference plasma (KANOBANA et al., 2001).

The positive standard plasma for $O$. ovis was obtained from a sheep that had been evaluated by means of titration tested by Silva et al. (2012b). For the negative control, plasma samples were obtained from young animals that were kept indoors without any contact with adult bot flies.

\section{Oestrus ovis larvae count postmortem}

After the lambs had been slaughtered, their heads were removed and were cut open along their longitudinal and sagittal axes. All larvae that were present in the nasal cavity (nasal passage, septum, middle meatus and conchae) and frontal sinus were collected and counted. The larvae were preserved in $70 \%$ ethanol and were identified according to their stage of development, based on the descriptions of Zumpt (1965) and Capelle (1966).

\section{Statistical analyses}

Descriptive statistical analyses were used to summarize the data on larval burden, in agreement with Bush et al. (1997), using the following terms:

Prevalence: the number of hosts infested with $O$. ovis larvae, divided by the number of hosts examined;

Intensity of infestation: the number of $O$. ovis larvae in a single infested host;

Mean intensity of infestation: the total number of $O$. ovis larvae found divided by the number of hosts infected with that parasite.

Significant differences between the quantities of L1, L2 and L3 larvae were assessed by the nonparametric Kruskal-Wallis test and Dunn's post-test was used for multiple comparisons. Statistical significance was set at $\mathrm{P}<0.05$. Pearson correlation coefficients were estimated between the larval burden and IgG levels at the time of the last sampling. Both of these tests were performed using the Minitab 11.21 statistical software (Minitab Inc., USA).

\section{Results}

The anti-O. ovis plasma IgG levels were high over the first three weeks of age with averages of $70 \%$ OD on the first week of birth and $61 \%$ OD at three weeks of age (Figure 2). The antibody levels then declined progressively until the lambs were 11 weeks of age, when the minimum mean value (23\% OD) was recorded. This coincided with the weaning period. From this time onwards, the antibody levels started to increase and reached their maximum values (average of 93\% OD) at the end of the trial (Figure 2).

All the three larval stages of $O$. ovis (L1, L2 and L3) were found in the 26 lambs, except in three animals that only had L1 and L2.
The intensity of infestation ranged from 10 to 97 larvae per animal (Figure 3). The mean intensity of infestation was 38.8 larvae per head with averages of 19.8 first-instar (L1) larvae, 11.6 secondinstar (L2) larvae and 7.4 third-instar (L3) larvae. There was a significant difference between the quantities of L1 and L3 larvae $(\mathrm{P}<0.05)$.

At the time of the last sampling, there were non-significant correlation coefficients between IgG levels and O. ovis larval burden (Figure 4).

Nasal discharges and sneezing were evident in sheep at the farm during the study, but the clinical symptoms of oestrosis were just mild in the lambs.

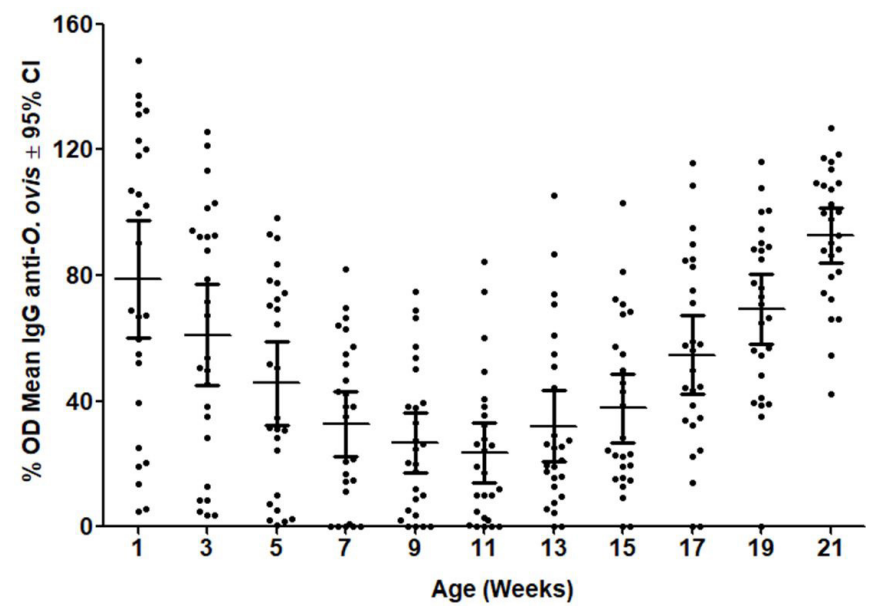

Figure 2. Mean optical density (OD) levels of plasma IgG against crude extract of second-instar larvae of Oestrus ovis in naturally infested lambs. CI, confidence interval.

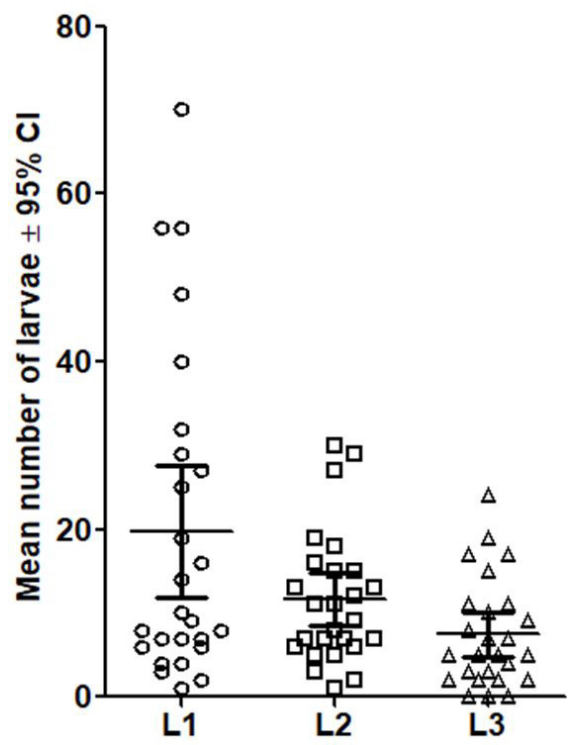

Figure 3. Mean number of first-stage (L1), second-stage (L2) and third-stage (L3) larvae in lambs naturally infested by Oestrus ovis. CI, confidence interval. 
$\mathbf{a}$

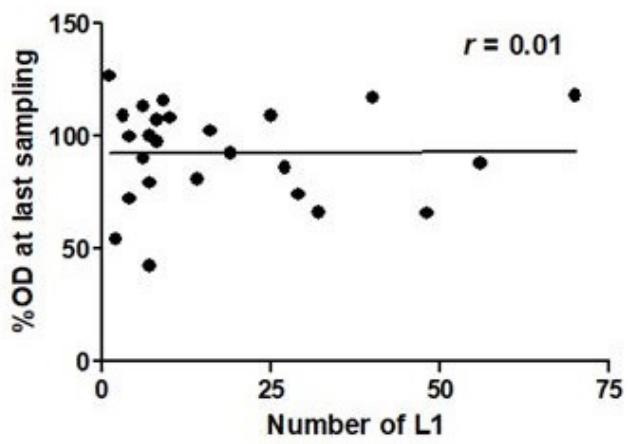

b

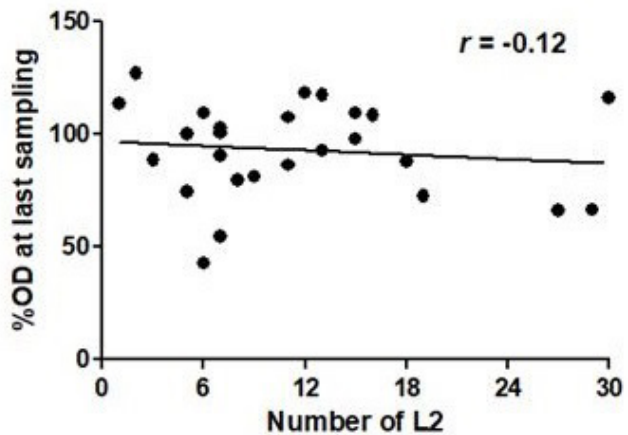

c

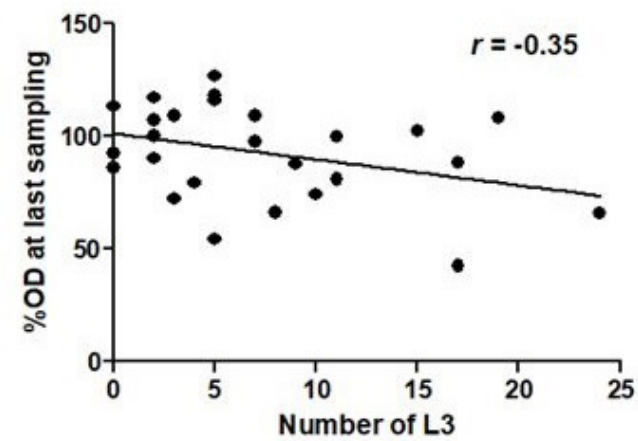

Figure 4. Relationship between IgG values (\%OD) and numbers of L1 (a), L2 (b) and L3 (c) at the last sampling. There was no significant correlation coefficients $(r)$ between variables $(\mathrm{P}>0.05)$.

\section{Discussion}

The anti-O. ovis IgG levels in the young lambs showed marked changes. High levels of $\operatorname{Ig} G$ were recorded over the first three weeks of life, thus indicating that maternal transfer of specific anti- $O$. ovis immunoglobulins to lambs had occurred through colostrum. Newborn lambs display ascendant colostrum absorption of gamma globulins during their first 24 hours of life followed by stabilization over the next few hours (ULIAN et al., 2014). The levels of these colostrum-acquired maternal antibodies progressively declined until the lambs were 11 weeks of age, i.e. at a time that coincided with weaning. The IgG levels started to increase again when the lambs were around 13 weeks of age and reached their apex on the last day of sampling.
Abo-Shehada et al. (2000) suggested that older sheep may be more attractive to $O$. ovis flies than are younger animals. Thus, while the lambs were with their mothers, the flies would preferentially target the adult ewes for larviposition. In other hand, lambs may become adequate hosts for gravid Oestrus females until they develop a reaction-defensive behavior in the presence of the parasite (PAPAVERO, 1977). In the present study, all 26 young lambs were infested by $O$. ovis, which indicated that in our environment, young animals are also very prone to be targeted as hosts by the flies. The acquired immune response against $O$. ovis was clearly demonstrated at 13 weeks of age, when the IgG levels started to increase, indicating that the animals had already become infested before that age.

It is known that colostrum contains antibodies against pathogens that are prevalent in a particular flock. Its function is to transfer protection from the mother to the young lambs before their own immunological response becomes fully functional (NOWAK \& POINDRON, 2006), thus helping prevent disease outbreaks among lambs. In the present study, it was clear that after infestation began, the lambs acquired a natural immune response. However, it seems that the presence of antibodies in the plasma was ineffective for protecting the lambs against $O$. ovis infestation. This indicates that the animals do not develop any protective immune response as a result of exposure (ABO-SHEHADA et al., 2000) or through antibodies transferred via colostrum.

Even beyond the neonatal stage, young sheep have greater susceptibility to infectious diseases, gastrointestinal parasite infections and ectoparasitic infestations than do older animals, and appear to be immunologically hyporesponsive (reviewed by DWYER, 2008). In the case of oestrosis, there are divergent views regarding acquisition of immunity. It has been shown that adult sheep seem to be less susceptible to $O$. ovis infestation than are young lambs, thus suggesting that continuously exposed sheep develop some immune competency (SCALA et al., 2001). On the other hand, it has also been suggested that the larval burden increase with age, thus indicating that the animals do not develop any protective immune response as a result of exposure (ABO-SHEHADA et al., 2000). The inflammatory response seems to be involved only in retardation of larval development and, in addition, successive infestations might induce a reduction of specific lymphocyte proliferation, thus suggesting that immunosuppression might be induced by the parasites (JACQUIET et al., 2005).

In the present study, all larval stages were recovered simultaneously, but the proportion of $\mathrm{L} 1$ in the lambs was significantly higher. This may be explained by the climatic conditions, which favored larval development with concomitant occurrence of reinfestation. Another possibility could be the retardation in larval development that is associated with high IgG response. However, no significant positive correlation was found in the present study, unlike what was demonstrated in other studies (FRUGËRE et al., 2000; JACQUIET et al., 2005; ANGULO-VALADEZ et al., 2007; SILVA et al., 2012b). Furthermore, the low prevalence of third-stage larvae could also be due to the rate of development and the brief time that third-stage larvae spend in the sinuses before they are expelled.

In conclusion, the lambs became infested with $O$. ovis at an early age and the larval burden was not associated with specific 
IgG levels. Since oestrosis is a common problem in sheep, a serological diagnosis may be useful for identifying animals that are carrying $O$. ovis and for avoiding underestimation of the number of parasitized animals, as often happens when using purely visual diagnostic methods (ARIAS et al., 2014).

\section{Acknowledgements}

Alessandro F. T. Amarante is a recipient of a fellowship from CNPq (Conselho Nacional de Desenvolvimento Científico e Tecnológico). César C. Bassetto (grant number 2010/18678-5) received financial support from FAPESP.

\section{References}

Abo-Shehada MN, Arab B, Mekbel R, Williams D, Torgerson PR. Age and seasonal variations in the prevalence of Oestrus ovis larvae among sheep in northern Jordan. Prev Vet Med 2000; 47(3): 205-212. http:// dx.doi.org/10.1016/S0167-5877(00)00160-4. PMid:11058780.

Alcaide M, Reina D, Sánchez-López J, Frontera E, Navarrete I. Seroprevalence of Oestrus ovis (Diptera, Oestridae) infestation and associated risk factors in ovine livestock from Southwestern Spain. J Med Entomol 2005; 42(3): 327-331. http://dx.doi.org/10.1093/jmedent/42.3.327. PMid:15962782.

Angulo-Valadez CE, Ascencio F, Jacquiet P, Dorchies P, Cepeda-Palacios R. Sheep and goat immune responses to nose bot infestation: a review. Med Vet Entomol 2011; 25(2): 117-125. http://dx.doi.org/10.1111/j.13652915.2010.00911.x. PMid:20880281.

Angulo-Valadez CE, Cepeda-Palacios R, Jacquiet P, Dorchies P, Prévot F, Ascencio-Valle F, et al. Effects of immunization of Pelibuey lambs with Oestrus ovis digestive tract protein extracts on larval establishment and development. Vet Parasitol 2007; 143(2): 140-146. http://dx.doi. org/10.1016/j.vetpar.2006.08.025. PMid:16979824.

Angulo-Valadez CE, Scala A, Grisez C, Prévot F, Bergeaud JP, Carta A, et al. Specific IgG antibody responses in Oestrus ovis L. (Diptera: Oestridae) infected sheep: associations with intensity of infection and larval development. Vet Parasitol 2008; 155(3-4): 257-263. http://dx.doi. org/10.1016/j.vetpar.2008.05.015. PMid:18584967.

Arias MS, Moreno V, Sarasa M, Paz-Silva A, Sánchez-Andrade R, Morrondo P, et al. Reliability of an ELISA test for diagnosing oestrosis in Iberian Ibex. J Parasitol 2014; 100(2): 235-238. http://dx.doi.org/10.1645/13190.1. PMid:24299554.

Arslan M, Kara M, Gicik Y. Epidemiology of Oestrus ovis infestations in sheep in Kars province of north-eastern Turkey. Trop Anim Health Prod 2009; 41(3): 299-305. http://dx.doi.org/10.1007/s11250-008-9190-x. PMid:18523857.

Ataíde HS, Cansi ER. Ocorrência das doenças parasitárias em ovinos e caprinos no Distrito Federal, Brasil, durante 2003 a 2009. Arq Inst Biol 2013; 80(3): 342-345. http://dx.doi.org/10.1590/S1808-16572013000300012.

Barroso P, Ruiz-de-Ybáñez R, Martínez-Carrasco C, Gens MJ, Escribano F, Sánchez A, et al. First report of oestrosis in aoudad from southeastern Spain. Parasitol Res 2017; 116(7): 2053-2055. http://dx.doi.org/10.1007/ s00436-017-5504-0. PMid:28508162.

Bush AO, Lafferty KD, Lotz JM, Shostak AW. Parasitology meets ecology on its own terms: Margolis et al. revisited. J Parasitol 1997; 83(4): 575583. http://dx.doi.org/10.2307/3284227. PMid:9267395.
Capelle KJ. The occurrence of Oestrus ovis L. (Diptera: Oestridae) in the bighorn sheep from Wyoming and Montana. J Parasitol 1966; 52(3): 618-621. http://dx.doi.org/10.2307/3276337. PMid:5942536.

Caracappa S, Rilli S, Zanghi P, Di Marco V, Dorchies P. Epidemiology of ovine oestrosis (Oestrus ovis Linné 1761, Diptera: Oestridae) in Sicily. Vet Parasitol 2000; 92(3): 233-237. http://dx.doi.org/10.1016/S03044017(00)00317-4. PMid:10962161.

Carvalho RS, Ruivo MA, Colli MHA, Pereira V, Martinez AC, Mazzucatto BC, et al. Occurrences of Oestrus ovis parasitism in necropsied sheep in the Umuarama microregion, Paraná, Brazil. Rev Bras Parasitol Vet 2015; 24(3): 370-374. http://dx.doi.org/10.1590/S1984-29612015044. PMid:26291142.

Cepeda Palacios R, Angulo-Valadez CE, Scholl P, Ramírez-Orduña R, Jacquiet P, Dorchies P. Ecobiology of the sheep nose bot fly (Oestrus ovis L.): a review. Rev Med Vet 2011; 162(11): 503-507.

Dorchies P, Bergeaud JP, Tabouret G, Duranton C, Prévot F, Jacquiet P. Prevalence and larval burden of Oestrus ovis (Linné 1761) in sheep and goats in northern Mediterranean region of France. Vet Parasitol 2000; 88(3-4): 269-273. http://dx.doi.org/10.1016/S0304-4017(99)00215-0. PMid:10714464.

Dorchies P, Duranton C, Jacquiet P. Pathophysiology of Oestrus ovis infection in sheep and goats: a review. Vet Rec 1998; 142(18): 487-489. http://dx.doi.org/10.1136/vr.142.18.487. PMid:9612915.

Dwyer CM. The welfare of the neonatal lamb. Small Rumin Res 2008; 76(1-2):31-41. http://dx.doi.org/10.1016/j.smallrumres.2007.12.011.

Fasih N, Qaiser KN, Bokhari SA, Jamil B, Beg MA. Human ophthalmomyiasis externa caused by the sheep botfly Oestrus ovis: a case report from Karachi, Pakistan. Asian Pac J Trop Biomed 2014; 4(10): 835-837. http://dx.doi. org/10.12980/APJTB.4.2014C901.

Frugère S, Leon AC, Prévot F, Palacios RC, Tabouret G, Bergeaud JP, et al. Immunisation of lambs with excretory secretory products of Oestrus ovis third instar larvae and subsequent experimental challenge. Vet Res 2000; 31(5): 527-535. http://dx.doi.org/10.1051/vetres:2000105. PMid:11050748.

Gebremedhin E. Prevalence of ovine and caprine oestrosis in Ambo, Ethiopia. Trop Anim Health Prod 2011; 43(1): 265-270. http://dx.doi. org/10.1007/s11250-010-9687-y. PMid:20725855.

Gomez-Puerta LA, Alroy KA, Ticona DS, Lopez-Urbina MT, Gonzalez AE. A case of nasal myiasis due to Oestrus ovis (Diptera: Oestridae) in a llama (Lama glama). Rev Bras Parasitol Vet 2013; 22(4): 608-610. http:// dx.doi.org/10.1590/S1984-29612013000400026. PMid:24473891.

Gracia MJ, Lucientes J, Peribáñez MA, Castillo JA, Calvete C, Ferrer LM. Epidemiology of Oestrus ovis infection of sheep in northeast Spain (mid-Ebro Valley). Trop Anim Health Prod 2010; 42(5): 811-813. http:// dx.doi.org/10.1007/s11250-009-9503-8. PMid:19937114.

Hanan BA. Seasonal prevalence of Oestrus ovis L. (Diptera: Oestridae) larvae in infested sheep in Jasan Region, Saudi Arabia. J Parasitol Vector Biol 2013; 5(5): 66-71.

Hidalgo A, Palma H, Oberg C, Fonseca-Salamanca F. Oestrus ovis infection of grazing sheep during summer in southern Chile. Pesq Vet Bras 2015; 35(6): 497-500. http://dx.doi.org/10.1590/S0100-736X2015000600002.

Jacquiet P, Tran Thi Ngoc T, Nouvel X, Prevot F, Grisez C, Yacob HT, et al. Regulation of Oestrus ovis (Diptera: Oestridae) populations in previously exposed and naïve sheep. Vet Immunol Immunopathol 2005; 105(1-2): 95-103. http://dx.doi.org/10.1016/j.vetimm.2004.12.024. PMid:15797479. 
Kanobana K, Vervelde L, Van Der Veer M, Eysker M, Ploeger H. Characterization of host responder types after a single Cooperia oncophora infection: kinetics of the systemic immune response. Parasite Immunol 2001; 23(12): 641-653. http://dx.doi.org/10.1046/j.1365-3024.2001.00426.x. PMid:11737667.

Matos V, Diego JGR, Alfonso P, Olivares JL. Oestrus ovis (Diptera: Oestridae): un importante ectoparásito de los ovinos en Cuba. Rev Salud Anim 2013; 35(2): 79-88.

Moreno V, Pérez JM, Moreno PA, Granados JE, Ruiz-Martinez I, Soriguer RC, et al. Oestrid myiasis in European Mouflon from Spain. J Wildl Dis 1999; 35(1): 78-81. http://dx.doi.org/10.7589/0090-3558-35.1.78. PMid:10073350.

Moreno V, Romero-Fernández I, Marchal JA, Beltrán M, Granados JE, Habela MA, et al. Molecular characterization of bot flies, Oestrus spp., (Diptera, Oestridae), from domestic and wild Bovidae hosts. Vet Parasitol 2015; 212(3-4): 473-477. http://dx.doi.org/10.1016/j.vetpar.2015.08.002. PMid:26298510.

Mustafa VS, Guedes KMR, Lima EMM, Borges JRJ, Castro MB. Doenças da cavidade nasal em pequenos ruminantes no Distrito Federal e no Estado de Goiás. Pesq Vet Bras 2015; 35(7): 627-636. http://dx.doi. org/10.1590/S0100-736X2015000700005.

Nowak R, Poindron P. From birth to colostrum: early steps leading to lamb survival. Reprod Nutr Dev 2006; 46(4): 431-446. http://dx.doi. org/10.1051/rnd:2006023. PMid:16824451.

Papavero N. The World Oestridae (Diptera), mammals and continental drift. Dordrecht: Springer Netherlands; 1977. http://dx.doi.org/10.1007/97894-010-1306-2.

Ramos CI, Bellato V, Souza AP, Avila VS, Coutinho GC, Dalagnol CA. Epidemiologia de Oestrus ovis (Diptera: Oestridae) em ovinos no Planalto Catarinense. Cienc Rural 2006; 36(1): 173-178. http://dx.doi. org/10.1590/S0103-84782006000100026.

Rao S, Radhakrishnasetty N, Chadalavada H, Hiremath C. External ophthalmomyiasis by Oestrus ovis: a case report from Davangere. J Lab Physicians 2018; 10(1): 116-117. http://dx.doi.org/10.4103/JLP. JLP_18_17. PMid:29403219.

Ribeiro VLS, Oliveira CMB, Branco FPJA. Prevalência e variações mensais das larvas de Oestrus ovis (Linneus, 1761) em ovinos no município de Bagé, RS, Brasil. Arq Bras Med Vet Zootec 1990; 42(3): 211-221.

Saleem T, Katoch R, Yadav A, Mir IA, Godara R, Ahamed I. Prevalence of ovine oestrosis in plain and Kandi areas of Jammu, north India. Int J Sci Environ Technol 2017; 6(2): 1117-1122.
Sánchez A, Caparrós N, Ostrowski S, Sarasa M, Pérez JM. Oestrosis in Asiatic ibex (Capra sibirica): a case report and molecular characterization of larvae. Vet Parasitol 2017; 236: 55-57. http://dx.doi.org/10.1016/j. vetpar.2017.02.003. PMid:28288765.

Sante Fernández L, Hernández-Porto M, Tinguaro V, Lecuona Fernández M. Ophthalmomyiasis and nasal myiasis by Oestrus ovis in a patient from the Canary Islands with uncommon epidemiological characteristics. Enferm Infecc Microbiol Clin 2017; 35(7): 461-462. PMid:26620606.

Scala A, Solinas G, Citterio CV, Kramer LH, Genchi C. Sheep oestrosis (Oestrus ovis Linné 1761, Diptera: Oestridae) in Sardinia, Italy. Vet Parasitol 2001; 102(1-2): 133-141. http://dx.doi.org/10.1016/S03044017(01)00515-5. PMid:11705659.

Schenkel DM, Cavalcante MKM, Damasceno ES, Campos AK, Furlan FH. Surto de Oestrus ovis em ovinos em Mato Grosso, Brazil. Pesq Vet Bras 2012; 32(8): 754-756. http://dx.doi.org/10.1590/S0100736X2012000800013.

Silva BF, Bassetto CC, Amarante AFT. Epidemiology of Oestrus ovis (Diptera: Oestridae) in sheep in Botucatu, State of São Paulo. Rev Bras Parasitol Vet 2012a; 21(4): 386-390. http://dx.doi.org/10.1590/S198429612012000400008. PMid:23295819.

Silva BF, Bassetto CC, Amarante AFT. Immune responses in sheep naturally infected with Oestrus ovis (Diptera: Oestridae) and gastrointestinal nematodes. Vet Parasitol 2012b; 190(1-2): 120-126. http://dx.doi. org/10.1016/j.vetpar.2012.06.004. PMid:22770703.

Silva BF, Bassetto CC, Shaw RJ, Canavessi AMO, Amarante AFT. Parasitism by Oestrus ovis: Influence of sheep breed and nematode infections. Vet Parasitol 2012c; 186(3-4): 437-444. http://dx.doi.org/10.1016/j. vetpar.2011.11.007. PMid:22105081.

Silva BF, Machado GP, Izidoro TB, Amarante AFT. Prevalence of Oestrus ovis (Diptera: Oestridae) in sheep from the São Paulo Central region, Brazil. Rev Bras Parasitol Vet 2013; 22(1): 18-21. http://dx.doi.org/10.1590/ S1984-29612013005000011. PMid:23538505.

Ulian CMV, Fernandes S, Ramos PRR, Dias A, Lourenço MLG, Chiacchio SB. Avaliação da absorção colostral em neonatos ovinos da raça Bergamácia. Arq Bras Med Vet Zootec 2014; 66(3): 705-712. http:// dx.doi.org/10.1590/1678-41625864.

Vasconcelos TC, Macêdo JTSA, Silva A, Silva MMN, Bittencourt TCC, Santos MVB, et al. Oestrose: uma parasitose emergente em pequenos ruminantes no Nordeste do Brasil. Pesq Vet Bras 2016; 36(10): 925-929. http://dx.doi.org/10.1590/s0100-736x2016001000001.

Zumpt P. Myiasis in man and animals in the Old World. London: Butterworths; 1965. 